\title{
IMPROVING STUDENTS' SPEAKING ABILITY THROUGH AIR WORK CONVERSATION TECHNIQUE AT MTS JA-ALHAQ OF BENGKULU CITY, BENGKULU, INDONESIA
}

\author{
DEDI EFRIZAL
}

\begin{abstract}
Abstrak: Penelitian ini dilakukan untuk meningkatkan kemampuan berbicara siswa melalui Teknik Percakapan Pasangan Kerja pada Siswa Kelas Dua Sekolah Menengah Pertama di Pondok Pesantren Ja-Alhaq Bengkulu pada tahun akademik 2017-2018. Subyek penelitian ini terdiri dari 30 siswa. Metode yang digunakan dalam penelitian ini adalah Penelitian Tindakan Kelas (PTK). Desain Penelitian Action Clasroom yang digunakan dalam penelitian ini adalah penelitian tindakan kelas kolaboratif. Artinya peneliti berkolaborasi dengan guru Bahasa Inggris Pondok Pesantren Ja-Alhaq Bengkulu sebagai pengamat dan kolaborator. Penelitian dilakukan dalam tiga siklus. Setiap siklus terdiri dari tiga pertemuan. Data dikumpulkan dalam penelitian ini melalui catatan lapangan, dan tes. Hasil penelitian menunjukkan bahwa ada peningkatan kemampuan berbicara siswa. Sebagian besar siswa secara bertahap mendapatkan nilai yang baik pada akhir setiap siklus. Kesimpulannya, Teknik Percakapan Pasangan Kerja dapat memecahkan masalah siswa dan meningkatkan kemampuan berbicara mereka.
\end{abstract}

Keywords: Students' Speaking Ability, Pair Work Conversation Technique.

\section{A. INTRODUCTION}

English has become one of the major courses since junior high school up to university level and now it is becoming a trend to start teaching English for elementary level. Unfortunately, the students have not gained as the expected skills of using the language inside and outside of the class. Their output in the language is limited inwriting patterned answers and producing grammatical accurately, but isolated sentences.

Real communication, however, involves ideas, emotions, feelings, appropriateness and adaptability. Yet, most conventional English classes today hardly give students an opportunity to use this language in this 
manner and develop fluency in it. Regardless any factor that affects, there has not been many activities proposing students focus more for real communication atmosphere. During the English classes, especially teaching for beginner students, teachers are used to merely completing hours of teaching with textbooks, written exercises, or grammar reviews.

Speaking is an interactive process of constructing meaning that involves producing and receiving and processing information (Brown, 1994; Burns \& Joyce, 1997). Its form and meaning are dependent on the context in which it occurs, including the participants themselves, their collective experiences, the physical environment, and the purposes for speaking. It is often spontaneous, open-ended, and evolving. However, speech is not always unpredictable. Language functions (or patterns) that tend to recur in certain discourse situations (e.g., declining an invitation or requesting time off from work), can be identified and charted (Burns \& Joyce, 1997). For example, when a salesperson asks "May I help you?" the expected discourse sequence includes a statement of need, response to the need, offer of appreciation, acknowledgement of the appreciation, and a leave-taking exchange. Speaking requires that learners not only know how to produce specific points of language such as grammar, pronunciation, or vocabulary (linguistic competence), but also that they understand when, why, and in what ways to produce language (sociolinguistic competence).

Many literatures (Brown, 2000: 48; Hughes, 1990: 104; Harmer, 1996: 73; Cohen, 1998: 209) suggest that the best way to engage students with learning a new language is to "jump in" directly with speaking practices promptly from the very beginning level. As Brown (2000: 57) states that over many decades of research of prominent methods of teaching English had come to a conclusion of finding communicative language teaching method that applies speaking techniques stretching from novice (beginner) to advance level. One of the best technique to 
apply in this term of learning is group work. Although Brown also states that differences between group work and pair work have not been emphasized. There are, in fact, some important distinctions. Pair work is more appropriate than group work for tasks that are (a) short, (b) linguistically simple, and (c) quite controlled in terms of the structure of the task (Brown, 2000: 178). Appropriate pair activities (that are not recommended for groups of more than two) include:

1. Practicing dialogues with a partner.

2. Simple question and answer exercises.

3. Performing certain meaningful substitution "drills".

4. Quick (one minute or less) brainstorming activity.

5. Checking written work with each other.

6. Preparation for merging with a larger group.

7. Any brief activity for which the logistics of assigning groups, moving furniture, and getting students into the groups is distractive.

Pair work enables the teachers to get students engaged in interactive (or quasi-interactive) communication for a short period of time with a minimum of logistical problems. The first step in promoting successful group work, then, is to select an appropriate task. In other words, choose something that lends itself to the group process. Lectures, drills, dictations, certain listening tasks, silent reading, a host of other activities are obviously not suitable for small group work. Brown then suggests following tasks which are most suitable for small group work (1994: 179): 1) games, 2) role-play and simulations, 3) drama, 4) projects, 5) interview, 6) brainstorming, 7) information gap, 8) jig saw, 9) problemsolving and decision making, and 10) opinion exchange. 
We as future English teachers need to have far exceedingly sufficient native-like speaking fluency so that the students will have their speaking resources and we can create the communicative environment for our future classes. Although it is impossible to say that a good speaking fluency is the only important focus to the exclusion of the other criteria a teacher should have. But, perhaps we can say that speaking fluency is measurement for communicative skills.

Learning to speak a foreign language requires more than knowing its grammatical and semantic rules. Learners must also acquire the knowledge of how native speakers use the language in the context of structured interpersonal exchange, in which many factors interact. Therefore, it is difficult for students to speak fluently and appropriately. In order to provide effective guidance in developing competent speakers of English, it is necessary to examine the factors affecting students' oral communication, components underlying speaking proficiency, and specific skills or strategies used in communication.

In this research, the researcher is trying to apply pair work conversation technique where the researcher pairs the students and encourage them to communicate in English all the time. This strategy will perhaps improve their speaking fluency significantly. According to Chamot (quoted in Kustati, 2007: 216), when learning is to take place, it involves collaboration of two people - a teacher to students or between students. In the classroom, the teacher introduces the students with controlled practices, relevant information, grammatical patterns and everything necessary for their pair work conversation. The pair work will be suggested to encourage students to work with their classmates, to use and to practice the functions and the forms they have already learned.

From these arguments, the researcher is eager to conduct a research and see how "pair work conversation" improve the speaking skill 
of $8^{\text {th }}$ grade students in MTs Ja-Alhaqof Bengkulu City. The consideration of choosing this school to be the research place is that there has never been any research conducted there and the school is one of the nearest school from the researcher permanent residence. Then the researcher proposes to conduct a research with the title, "improving students' speaking ability through pair work conversation technique at MTs Ja-Alhaq of Bengkulu City".

B. FINDINGS AND DISCUSSION

1. Findings

a. Cycle I

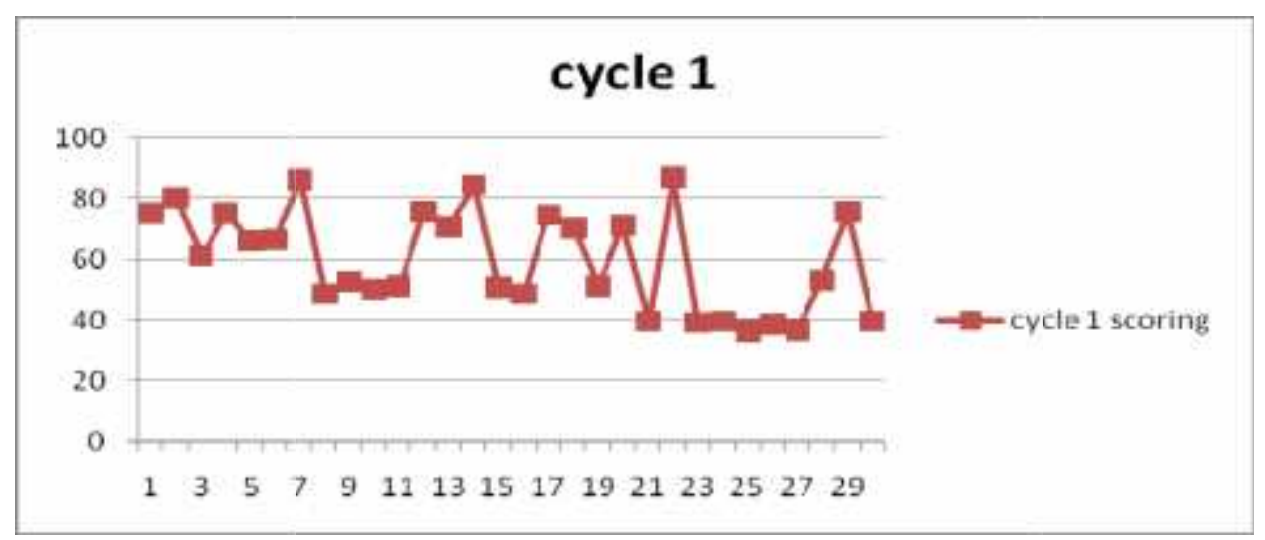

Chart 1: Students' Speaking Score in Cycle I

From the figure above, the students' score is into percentages. The percentages can be seen from the following table:

\begin{tabular}{|c|c|c|c|}
\hline \multirow[b]{2}{*}{ Interval } & \multirow[b]{2}{*}{ Qualification } & \multicolumn{2}{|l|}{ Cycle I } \\
\hline & & $\begin{array}{l}\text { Number } \\
\text { Students }\end{array}$ & Percentages \\
\hline $85-100$ & Excellent & 2 & $6.66 \%$ \\
\hline $71-84$ & Very good & 8 & 26.66 \\
\hline $60-70$ & Good & 6 & $20 \%$ \\
\hline $40-59$ & Low & 7 & $23.33 \%$ \\
\hline $0-39$ & Failed & 7 & 23.33 \\
\hline
\end{tabular}

Table 2: The Distribution of Students' Speaking in Cycle I 
From the table above, it can be seen that there is improvement in students' speaking. The data shows that $6.66 \%$ of students are excellent categories, 26\% are very good, 20\% are good categories, $23.33 \%$ are low categories and $23.33 \%$ are failed. Based on the evaluation and reflection, researcher and collaborator conclude that there is improvement in students' speaking. However, researcher feels that it is important to increase students' speaking because indicator of success has not been reached yet because some of students are still lack of motivation, lack of practice, and they are not active enough. Therefore, researcher and collaborator need to do action again.

b. Cycle II

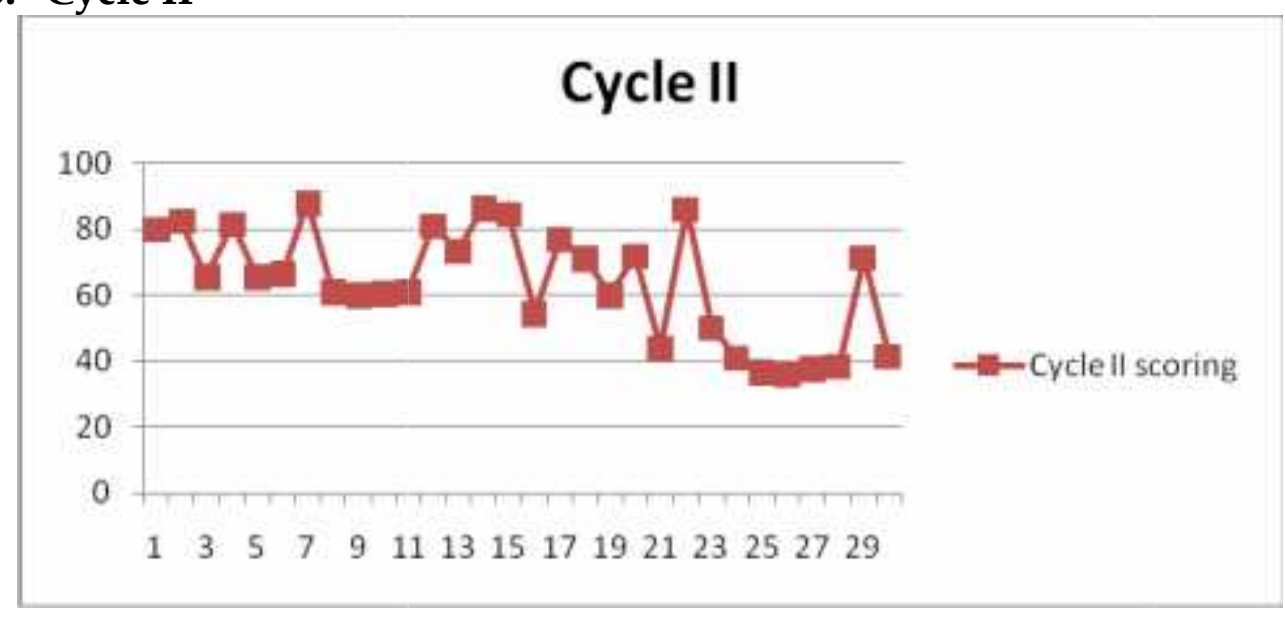

Chart 2: Students' speaking Score in Cycle II

From the figure above, the researcher collect the students' speaking score into percentages. It can be seen from the following table:

\begin{tabular}{|c|c|c|c|c|}
\hline \multirow[b]{2}{*}{ Interval } & \multirow[b]{2}{*}{ Qualification } & \multicolumn{3}{|l|}{ Cycle II } \\
\hline & & $\begin{array}{l}\text { Number } \\
\text { Students }\end{array}$ & of & Percentages \\
\hline $85-100$ & Excellent & 3 & & $10 \%$ \\
\hline $71-84$ & Very good & 9 & & $30 \%$ \\
\hline $60-70$ & Good & 8 & & $26.66 \%$ \\
\hline $40-59$ & Low & 6 & & $20 \%$ \\
\hline $0-39$ & Failed & 4 & & $13 \%$ \\
\hline
\end{tabular}

Table 3: The Distribution of Students' speaking in Cycle II 
From the table above, it can be seen that students' speaking increase in teaching speaking activity. It shows that $10 \%$ of student total numbers are categories excellent, 30\% are very good, 26,66\% are good, 20\% are low and $13,33 \%$ are failed categories.

From the data above, researcher feels that the indicator of success has not been reached yet because there are some problems in teaching speaking activity. That is why, researcher and collaborator think that it is important to over comes the problem in order indicator of success can be reached. Therefore, it is needed to do next cycle.

\section{c. Cycle III}

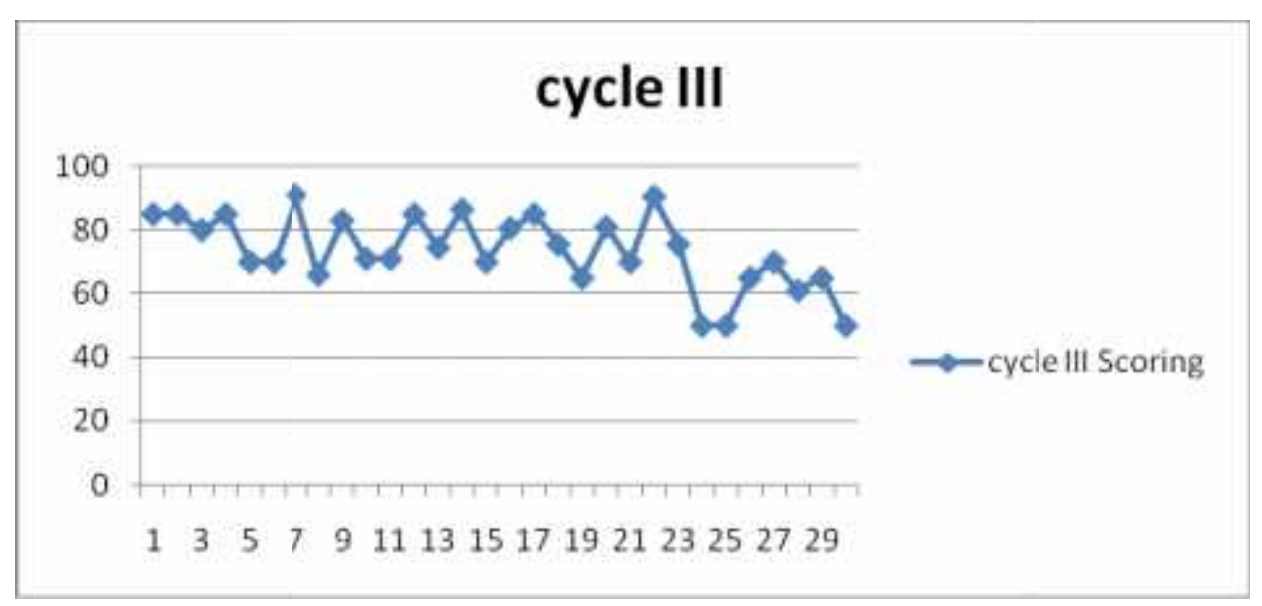

Figure 3. Students' speaking Score in Cycle III

From the figure above, the researcher collects the students' speaking achievement into percentages. The percentages can be seen from the following table: 


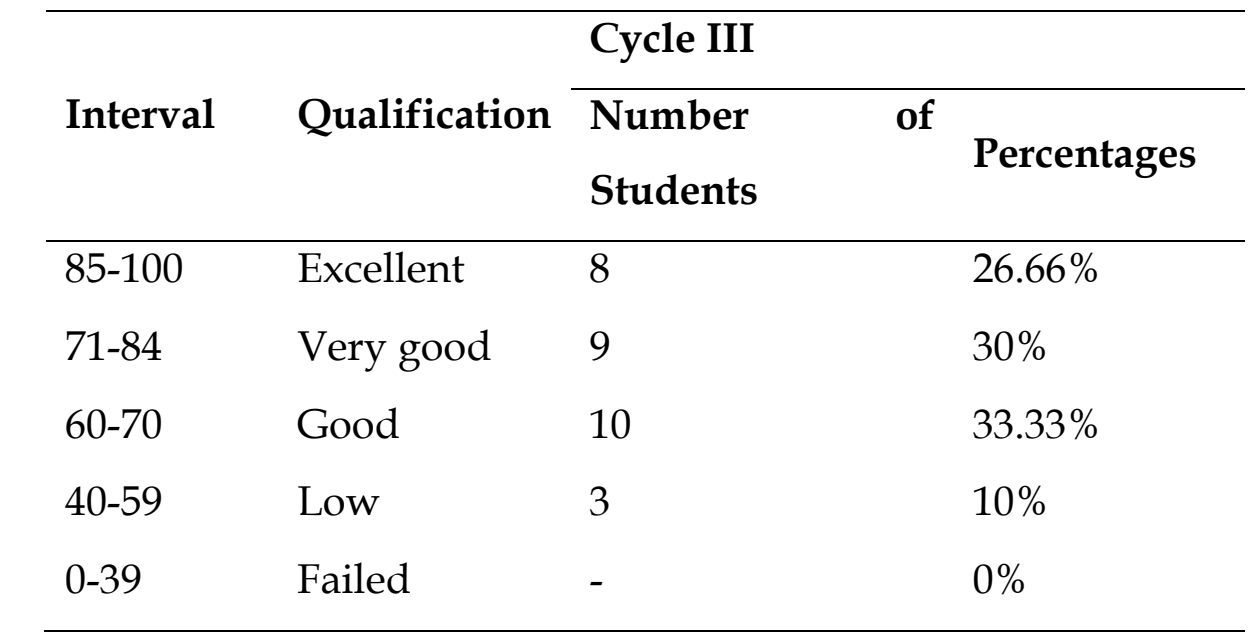

Table 4: The Distribution of Students' speaking in Cycle III

From table above above, it can be concluded that any progrees on students' speaking. It show that $26,66 \%$ students who are excellent categories, $30 \%$ are very good, 33,33\% are good, $10 \%$ are low and $0 \%$ is failed. From the result above, the researcher and collaborator conclude that the indicator of teaching in learning has been reached. Therefore, the researcher decided to stop the action.

\section{Discussion}

Based on the results which found by researcher in each cycles of this research, we could see that most of students were interested in learning English through Pair Work Conversation Technique. They had good selves-confidence to express their ideas in learning activity inside classroom, most of them could decrease their fears and rigidness to practice English skill, the frequency and percentage of students' vocabulary mastery were increased well in each cycles. In addition, Pair Work Conversation Technique could motivate the students to be active and had a great participation in speaking activity during teaching and learning process in classroom. 


\section{CONCLUSION}

Method or strategy is one of important things that must be applied during teaching and learning process in order the purpose of teaching can be reached and the students could enjoy the learning process without thinking that learning English is horrible subject. One of the strategy can be applied in teaching English speaking is Pair Work Conversation Technique because by applying the strategy, teaching English speaking can be more effective, and it is able to improve students' speaking ability, especially in Islamic boarding school.

Author :Dedi Efrizal, M.Pd (efrizaldedi279@gmail.com) State Institute of Islamic Studies (IAIN) of Bengkulu. Indonesia.

\section{REFERENCES}

Brown, H.D., (1994), Teaching by Principles: an Interactive Approach to Language Pedagogy, Englewood Cliffs, NJ: Prentice Hall Regents.

Burns, A., \& Joyce, H., (1997), Focus on Speaking, Sydney: NationalCenter for English Language Teaching and Research

Chamot, A. U., (1993), Student Responses to learning strategy instruction in the foreign language classroom, Foreign Language Annals 26: 308-321.

Cohen, A. (1998). Developing the Ability to Perform Speech Acts.Studies in Second Language Acquisition, 18 (2), 253-267.

Harmer, J., (2001),How to Teach English, England: Addison Wesley Longman

Hughes, Arthur, (1990), Testing for Language Teachers, Sydney: CambridgeUniversity Press 
Hughes, Rebecca. 2006. Spoken English, TESOL, and applied Linguistics: Challenges for Theory and Practice. Great Britain: CPI Antony Rowe

Latief, M Adnan. 2012. Research Methods on Language Learning: An Introduction. Malang: UM Press

Nunan, D. C., (1989), Designing Tasks for the Communicative Classroom, Cambridge: CambridgeUniversity Press

Rickheit, Gert and Strohner, Hans. 2008. Handbook of Communication Competence. Germany

Savignon, S.J., (1983), Communicative Competence: Theory and Classroom PracticeReading, MA: Addison-Wesley.

Thornbury, Scott and Diana Slade. 2007. Conversation: From Description to Pedagogy. New York: Cambridge University Press 